\title{
Public perception of nature conservation promotion in public spaces in Warsaw
}

Department of Animal Genetics and Conservation, Institute of Animal Sciences, Warsaw University of Life Sciences

e-mail: julia_maciocha@sggw.edu.pl

\section{Keywords:}

nature conservation, biodiversity, public space, education, citizen perception

\begin{abstract}
The purpose of this preliminary study was to learn about citizens' perceptions of promotion activities related to wildlife and nature conservation in public spaces in Warsaw, Poland. One hundred and fifty individuals, randomly approached, agreed to participate in the survey, 48 of whom were professionals in natural sciences. The survey contained 13 substantive questions, whereby predefined answers or were open-ended. The vast majority ( $81 \%)$ of respondents were interested in nature and environmental problems. They expressed views that the current efforts and activities in Warsaw to promote conservation of nature and endangered wild animal species are insufficient. In most cases, the respondents were able to list some activities for nature education they had observed in a number of the city's public spaces. The survey suggested that age and education of the respondents did not affect their attitudes toward nature conservation. However, the survey did indicate that women were more interested and concerned with nature protection than men, and they were willing to take part in the survey, when approached, more often than men. This study helps to consider directions for further research in this area.
\end{abstract}

o IOŚ-PIB

\section{INTRODUCTION}

The importance of society's awareness of biodiversity; its economic, social, and environmental values; and the need for active conservation has been underlined in many research studies [e.g. Kalinowska 2011; Rosa and Collado 2019]. The key role of citizens in biodiversity conservation and sustainable use was recognized by the Parties to the Convention on Biological Diversity when adopting a Communication, Education, and Public Awareness (CEPA) program at their sixth conference in 2002 [CBD 2002; Hesselink at al. 2007]. The need for citizen involvement was further highlighted by the inclusion of this area in 20 Aichi Targets of the Strategic Plan for Biodiversity 2011-2020 of the Convention. Target 1 states that "by 2020 at the latest, people are aware of the values of biodiversity and the steps they can take to conserve and use it sustainably" [CBD 2010]. Indeed, with knowledge and awareness, citizens and stakeholders are more likely to include biodiversity considerations into their daily lives and practices. The establishment of the United Nations Decade on Biodiversity by the United Nations General Assembly provided a good opportunity to draw attention to the importance of biodiversity to the well-being of humans and to pass this message to society.
The state of knowledge of the society has a high impact on the effectiveness of nature conservation [Gadotti 2008]. Building and maintaining high societal awareness of values of nature and conservation require sound investments in public education. Citizen education will provide the basis for developing positive attitudes and respect toward biodiversity and recognition of the value of nature and needs of its proper management and protection. An attractive educational message, adapted to a specific group of recipients, has proven to develop understanding and appreciation on the critical need to maintain healthy wildlife species and ecosystems, as well as build positive attitudes by citizens toward nature conservation and the required management investments.

Technological advancements and widespread of social media make the availability and numerous and varied options for transferring information and knowledge [Sánchez et al. 2014], as well as promotion of learning through play. New tools like multimedia billboards or apps for cell phones or other interactive devices are commonly used. Some educational activities undertaken in Warsaw include thematic campaigns using tools such as billboards, public transport monitors, or information plates. Educational short videos in underground transportation 
networks provide effective means of communication, reaching a large audience every day.

Education in the field of nature protection is also supported by events and competitions organized for city residents-both at local and international levels. Examples include: the European Green Capital initiative [organized by the European Commission], the European Capital of Biodiversity [Deutsche Umwelthilfe in cooperation with ICLEl and IUCN], or the Entente Florale Award granted to the city with the most beautiful vegetation [Kronenberg 2012]. Field-based education initiatives are also systematically increasing, with events and public lectures further enhanced with on the ground observations [ReferowskaChodak 2012].

The research carried out by Guzal-Dec and Zwolińska-Ligaj [2016] strongly indicated that there is great demand in Poland for activities by local authorities in the dissemination of ecological-based knowledge, and that such activities can play a key role in shaping society's attitudes. For example, revitalization of public spaces in cities, including various types of green areas that are prone to degradation, were enhanced in the recent years [Strzelecka 2011]. The preservation of green spaces in urban areas has shown to have great social importance. A research group at Sheffield University proved that the presence of green areas in cities provides positive impacts on local social and health wellbeing of citizens and promotes support for educational and sustainable development programs [Swanwick et al. 2003]. The possibility of observing wild species in the natural environment increases people's interest in ecological education [Górecki et al. 2007], and personal experiences with nature are associated with increased proenvironmental attitudes and behaviors [Rosa and Collado 2019].

Currently, various non-governmental organizations are engaged in supporting education through thematic events that highlight various nature conservation issues and needs, focusing on different groups of recipients. Examples of such activities in Poland include, World Wildlife Fund's billboard campaigns about Lynx [2018], adoption of bees' actions by Greenpeace [2019], and happenings for the protection of rivers by the Gaja Club [2019]. There are also many local projects to create habitats in cities that support existence of various synanthropic wildlife species, including for bees, bats, birds, and hedgehogs. However, the responsibility to implement CEPA lays with governmental, administration, and selfgoverning authorities, and their actions and programs need to provide opportunities to educate citizens and build awareness and positive attitudes toward nature and wildlife protection.

The aim of this study was to find out if citizens of Warsaw, who were randomly approached, would like to participate in the survey. We asked if they have any interest in the nature and wildlife, if they have been observant and paid any attention to the information present in the public spaces of the city on nature conservation, and what are their perceptions of such educational activities. The study was preliminary and aimed to increase understanding of general attitudes of respondents toward nature protection and to provide directions for further research.

\section{MATERIAL AND METHODS}

The study was conducted in various public places in Warsaw, the Polish capital city, by randomly requesting people to participate in the survey. People were approached randomly, and approximately a similar number of men and women were asked to take part in the survey. The study involved in total 150 individuals-112 women and 38 men-over the age of 18 who agreed to take part in the survey. Public places were selected to ensure a diversity of respondents and included places such as kindergarten facilities, colleges, medical clinics, restaurants, research institutes, and city parks.

The survey contained 17 questions, of which four gathered information on the respondents. The other 13 questions aimed at obtaining their personal assessment of the need to promote conservation of wildlife in the city's public spaces and the effectiveness of actions being undertaken in this respect.

The survey gathered information on whether respondents were personally interested/involved in matters related to nature protection, whether they were aware of examples of specific nature protection activities, and how they assessed projects that were aimed to increase citizens' involvement in biodiversity protection. Other questions were meant to identify the most preferable and used communication forms and channels, and to define the most-effective ways to persuade people to get involved or contribute to the protection of nature and wildlife.

The majority of respondents (75\%) were women, because they were willing when approached to take part in the research, contrary to men. The age distribution was similar in both sexes; however, the highest share in the group of respondents were people in the youngest age group, between 18 to 29 years old (30.7\%). The share of remaining four age groups was quite uniform between $14.7 \%$ and $20 \%$. Most of the respondents had higher or secondary education $(82 \%)$, with $3 \%$ having only primary education. About $32 \%$ of survey participants declared professional connections with the area of life sciences.

\section{RESULTS}

\section{Respondents' interests}

In a group of 48 respondents associated professionally with the life sciences, $96 \%$ declared interest in nature protection. In a group of remaining 102 respondents, who on a daily basis had no direct contact or education in this field, $75 \%$ expressed interest in nature conservation $(79 \%$ of women and $63 \%$ of men). In total, out of all respondents, 122 interviewed people (81\%) were interested in nature and wildlife protection, with that being $85 \%$ of women and $71 \%$ of men. 
Table 1. Scope of conservation measures proposed by the respondents

\begin{tabular}{|c|c|c|}
\hline Category & Proposed actions/activities & Number of replies \\
\hline $\begin{array}{c}\text { Species } \\
\text { protection }\end{array}$ & $\begin{array}{l}\text { - mammals and birds feeding } \\
\text { - building animal booths/nests for bats and birds } \\
\bullet \text { hotels for insects } \\
\text { - gateways and wildlife corridors } \\
\bullet \text { road fencing } \\
\bullet \text { controlled hunting/poaching }\end{array}$ & 42 \\
\hline $\begin{array}{c}\text { Areas of } \\
\text { protection }\end{array}$ & $\begin{array}{c}\bullet \text { establishment of national parks and reserves } \\
\bullet \text { designation of protected areas } \\
\text { - protection of shelters and wintering areas against human intervention } \\
\bullet \text { installation of soundproof screens }\end{array}$ & 26 \\
\hline Funding & $\begin{array}{c}\bullet \text { fundraising } \\
\bullet \text { donating } 1 \% \text { of the annual tax } \\
\text { - financing specific protection measures or projects }\end{array}$ & 19 \\
\hline Population size & $\begin{array}{l}\text { - monitoring of population size } \\
\text { - animal identification [tagging] } \\
\text { - reintroduction of endangered species }\end{array}$ & 10 \\
\hline Society & $\begin{array}{c}\bullet \text { foundations } \\
\text { • nongovernmental organizations } \\
\bullet \text { education } \\
\text { • films on nature protection } \\
\bullet \text { themed talks } \\
\text { - more frequent talk about endangered species }\end{array}$ & 8 \\
\hline
\end{tabular}

\section{Knowledge}

The respondents were asked to list all methods and types of activities they knew or heard about that were used in nature protection. All replies to this open question were divided post-factum into groups/categories as presented in Table 1. Forty-five participants (30\%) did not provide an answer to this question or declared their lack of knowledge of the subject.

The respondents were asked if they noticed any activities in public spaces in Warsaw that were related to nature protection, and if so, what was the topic of these activities and what were the issues or species concerned. Almost $80 \%$ of the respondents with biological sciences background (38 people) confirmed that they had noted promotion of nature protection in public spaces. In the group not professionally involved in life sciences, 54 people (53\%) answered positively to this question. Among the listed actions promoting species protection, the most often mentioned was protection of the lynx (13), wolf (11), and birds in general (10).

Respondents were asked to indicate the location of the observed actions to educate citizens or to promote the topic and the form in which nature protection was presented there. Places indicated by respondents included parks, the subway, and bus stops, as well as specific streets in Warsaw. Most respondents indicated television as their major source of information on issues related to

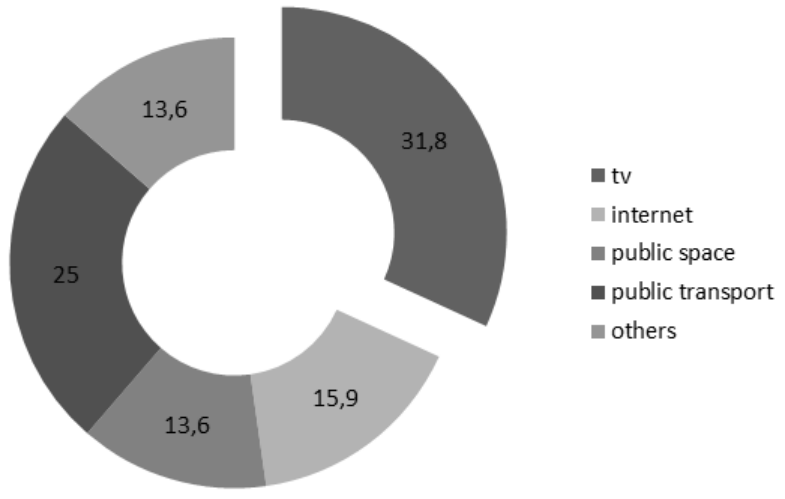

Figure 1. Distribution of places where actions promoting nature conservation were observed [\%]

nature protection (31.8\%). Respondents from each age group mentioned programs on nature protection on television - this was the most common answer, which proves the strength of the impact of mass media in delivering conservation messages (Figure 1). A large group of respondents indicated the Internet and social media as other places they encountered content related to nature and species protection.

With regard to information transfer, video spots were repeatedly indicated as the most common form of educational campaigns ( $46 \%$ of responses), with posters 


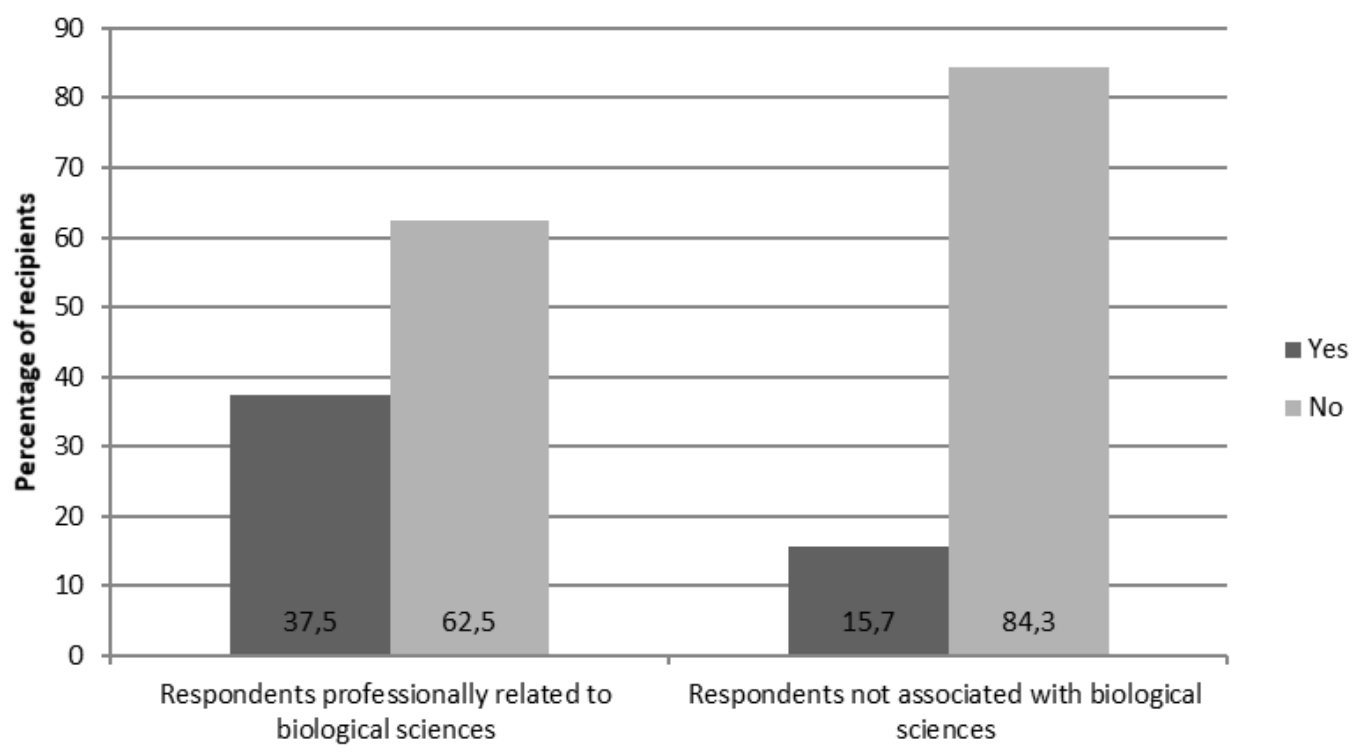

Figure 2. Distribution of respondents considering that actions for nature protection are sufficient [\%]

holding second place, (30\%). Other responses included radio broadcasts, happenings, theme events, and leaflets.

\section{Attitudes}

The third part of the study was to determine whether promotion of nature conservation is needed and what activities are the most desirable. Out of 150 respondents, only four (less than 3\%), stated that environmental protection measures are unnecessary; all of these respondents had secondary education and the sex ratio was equal. Thus, the vast majority of respondents, over $97 \%$, stated that promotion of nature conservation is needed.

The next questions were meant to assess whether, in the view of respondents, activities promoting protection of nature and endangered wild animal species are sufficient, and it also allowed respondents to indicate the priority species that they think should be considered as requiring most urgent conservation measures. There were significant differences in opinion on this topic between groups. As many as $37.5 \%$ of people from the first group of respondents, professionally related to life sciences, were of the opinion that the current level of promotion of nature protection is sufficient. In the second group, not involved in this area on a daily basis, only $15.7 \%$ of respondents shared this view (Figure 2).

Among the priority species that require special protection measures, many proposals were put forward. Only a few respondents indicated commonly known Polish charismatic species such as the stork, white-tailed eagle, or crane. The most frequently mentioned species was the wolf (26), then bear (16), and lynx (13). Respondents also pointed out animal species that are easily remembered because of their characteristic appearance such as bison (9) or beaver (8). It is important to mention that some respondents were not able to name individual species and instead indicated groups like birds or bees. Other respondents suggested conservation of common species such as the hare, rod deer, and wild boar.

\section{Preferences}

The last question allowed respondents to choose one option/reward, which, in their view, would be most effective in encouraging participation in a program for the protection of wild animal species and nature conservation (Figure 3). The most chosen reward were discount coupons, which were indicated in total by $36 \%$ of respondents. Although respondents represented all age groups, most respondents choosing this option belonged to the youngest and the oldest age group (50\% and $41 \%$, respectively).

The specific nature protection campaigns and obtaining gadgets were considered as attractive incentives for $17 \%$ of respondents each. Thematic gadgets proved to be more attractive for older respondents (24\%). With regard to nature protection as an imperative for ecotourism, the highest interest was expressed in the group of people between 40 and 49 years of age (23\%), in comparison with $11 \%$ for all other respondent age groups.

\section{DISCUSSION}

The study showed a higher willingness to participate in the survey on nature and wildlife by woman than men, as shown before by Curtin et al. [2000] and Smith [2008] and by younger rather than older people as reported by Moore and Tarnai [2002].

In spite of many efforts and actions taken to communicate on the importance of nature conservation, progress in 


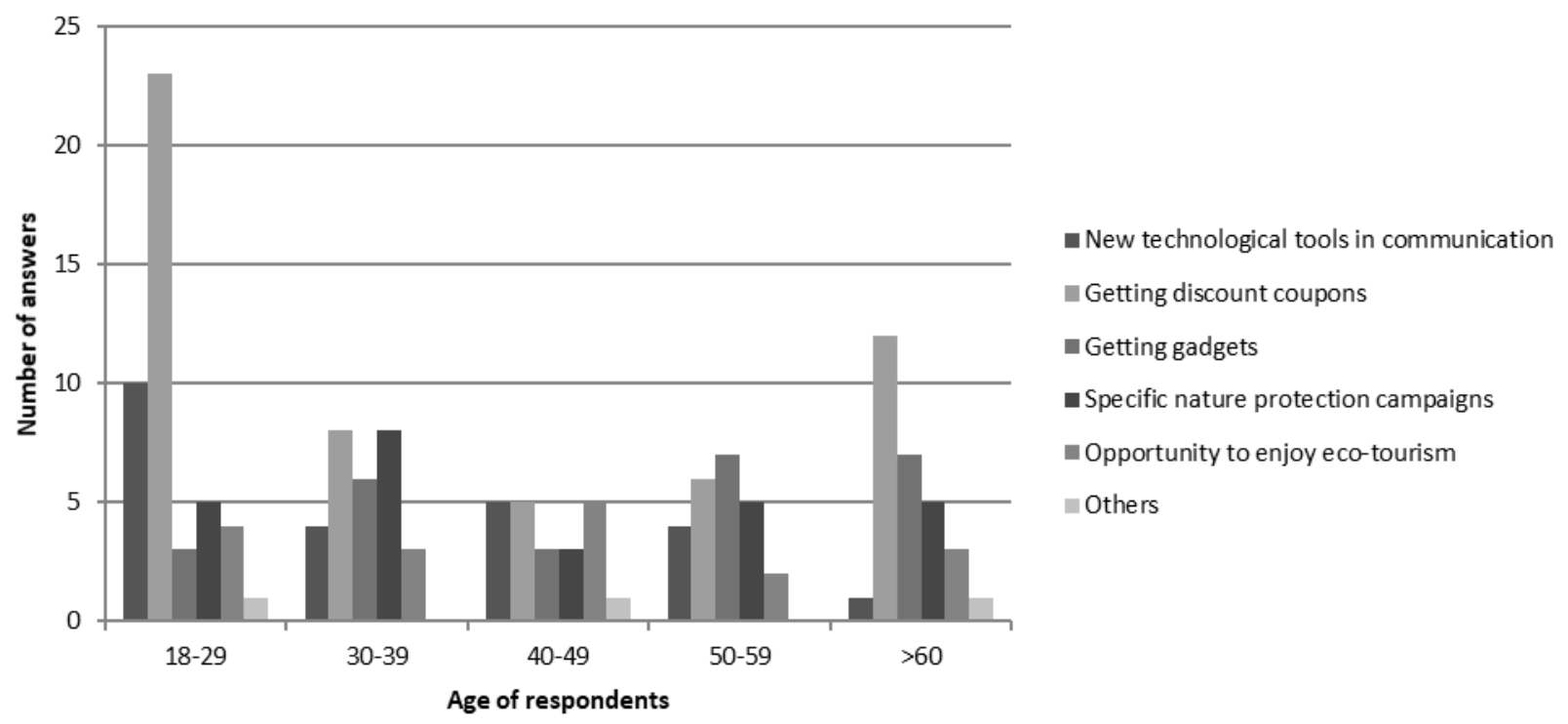

Figure 3. Preferences of respondents regarding encouragement measures to support nature conservation

changing attitudes and enhancing public awareness is slower than expected [Kalinowska 2011]. This conclusion is supported by the results of this study, where $30 \%$ of respondents were not aware of the methods of nature conservation.

In Eurobarometer assessment, $65 \%$ of Polish responders felt well-informed about environmental issues [European Commission 2014]. Unfortunately, this feeling did not translate into actual knowledge in this field or current behavior, as Polish respondents were, in various aspects, a few percent behind the EU28 average. In the current study, respondents were able to name only flagship species, often showing a lack of understanding of what species means. When asked about species that should be protected, many responses indicated species already protected or common species that are in abundance in Poland.

The study suggests that either the education on this topic is insufficient or methods and tools to strengthen and maintain this knowledge are not effective. This, unfortunately, may suggest also insufficient primary education, which results in insufficient knowledge of adults and their lower awareness of nature-related issues. Therefore, respondents participating in this study also might be less observant and perceptive of campaigns undertaken in Warsaw to bring nature conservation issues into public spaces. Promotional projects cannot effectively reach people unless they have a sufficient knowledge base that would help them understand problems and the cause-and-effect sequence [Vicente-Molina et al. 2013]. In our study, almost 32\% of people indicated television as a main source of their information about environment. Other studies show that importance of TV as a source of information is slowly declining in favor of social media, which creates new opportunities [Gerhards and Schäfer 2010; Robelia et al. 2011]. Indeed, technological progress in social communication has made information transfer and sharing using the Internet and social media extremely popular [Kirtis and Karahan 2011; Sánchez et al. 2014]. In our study, respondents also highly rated the Internet as a tool for obtaining information on nature protection $(15.6 \%$ of respondents).

The problem, however, is not only the form for obtaining information but trust that society has in the sources of the information. According to Eurobarometer, $40 \%$ of Polish people trust television, while only $28 \%$ trust scientists, and $23 \%$ trust environmental protection agencies. This result falls away from the EU28 average (respectively 34\%, 40\%, $37 \%)$ and is far away from such societies as in Sweden where $69 \%$ and $60 \%$ of citizens trust information provided by scientists and environmental agencies, respectively, and only $30 \%$ trust television sources [European Commission 2014].

The results of this study indicate significant interest in nature conservation, which was declared by $75 \%$ of the respondents not professionally related to life sciences, and $96 \%$ of those who were. This indicates growing openness and sensitivity of respondents to nature protection problems. Seventy-five percent of people in Poland agreed with the following statement that "As an individual, you can play a role in protecting the environment in [your country]" [European Commission 2014]. It is very important to offer to those interested a variety of actions to which they can personally contribute. One of the most important aspects of conservation of environment and biodiversity, which can include society, is monitoring and inventory.

In Poland, one of the most popular actions involving citizens to actively protect nature was the "Horseshoe Trail" project. The campaign, which was organized through EU subsidies for the protection of the lesser horseshoe bat, allowed monitoring populations of this species and 
generally encouraged people to learn more about bats [Węgiel et al. 2011]. Participation and work of local residents supports continuation of various biodiversity monitoring projects even with limited budgets [Parr et al. 2003]. In the United Kingdom, the British Trust for Ornithology has been operating for over 40 years, and through its campaigns, has interested not only scientists, but also members of society and politicians [Greenwood, 2003]. Wider participation of local people and community organizations interested in conducting environmental monitoring brings people closer to the problems of surrounding nature, and the data they collect improves knowledge of nature contributing to solving environmental problems, both today and in the future [Lovett et al. 2007].

Our own observations suggest that in Warsaw, compared to other European cities, public spaces are rarely used as places for nature conservation education. In our public transport, you can learn English every day, but it is difficult to learn about native species of fauna and flora, see photos from our national parks, or learn more about the Natura 2000 network. Despite billboards surrounding us everywhere advertising hundreds of products and events, few posters promote nature protection with simple messages that would reach the hearts and minds of Warsaw citizens.

In this study, age and education did not affect the level of interest of respondents in nature conservation; however, we have observed that $50 \%$ of the youngest respondent favored direct financial benefits as encouragement for nature conservation. This may suggest that younger people see lower altruistic values for biodiversity expecting material benefitsin return for taking action to protectnature. This may be caused by many factors, including growing alienation from the natural world, increased urbanization, wide use of time-consuming web technologies, and the perception of natural places as insecure [Rosa and Collado 2019]. Researchers have warned that lack of experiences in nature may have negative consequences for people's proenvironmentalism [Evans et al. 2018].

Some differences related to the sex of respondents were observed in this study. Women were both more interested in issues related to nature and felt a greater need to take action for nature protection. Perhaps this is due to greater sensitivity and the need for care inscribed in the role of women as mothers, as well as care for own health and family health, which may translate into the need to care for the environment and nature. Women are more likely than men to worry about the impact on human health from chemicals used in everyday products [European Commission 2014.] According to other research, women are also more aware consumers, pay attention to labels and product composition, and they are more likely to buy organic products [Lea and Worsley 2005]. Interest in such products and their method of production often leads to broadening ecological knowledge and greater sensitivity of environmental and nature issues. In our study, first of all, women much more often agreed to participate in the survey, and more often than men declared concern regarding the state of nature. These observations strongly corresponds with Eurobarometer 416 results [European Commission 2014].

\section{CONCLUSIONS}

Warsaw residents show high interest in nature conservation and protection of endangered animal species ( $81 \%$ of respondents). Women (84.8\%) declared more interest in nature's problems and a greater need for measures to promote its protection than men (71.1\%). However, answers of some respondents indicated that their knowledge of the issue is very low, which indicates a need for broader environmental education of the whole society.

The social demand for content promoting nature protection is greater than its availability in public spaces in Warsaw. Promoting protection of nature and endangered animal species in Warsaw is in the view of respondents unsatisfactory (78\%). As much as $39 \%$ of respondents participating in the survey have never encountered such activities. Mass media, such as television and the Internet, have been identified as the most effective tools used to promote nature protection.

\section{REFERENCES AND LEGAL ACTS}

Bee project. 2019. Greenpeace. https://adoptujpszczole.pl/ access 1.07.2020

CBD. 2002. Convention on Biological Diversity, Decision $\mathrm{VI} / 19$ Communication, education and public awareness UNEP/CBD/COP/DEC/VI/19.

CBD. 2010. Convention on Biological Diversity, Decision $X / 2$. The Strategic Plan for Biodiversity 2011-2020 and the Aichi Biodiversity Targets UNEP/CBD/COP/DEC/X/2

CURTIN, R., PRESSER, S., \& SINGER, E. 2000. The effects of response rate changes on the index of consumer sentiment. Public Opinion Quarterly 64: 413-428.
European Commission. 2014. Attitudes of European Citizens towards the Environment Special Eurobarometer 416. https:/lec.europa.eu/commfrontoffice/publicopinion/ index.cfm/Survey/getSurveyDetail/instruments/ SPECIAL/surveyKy/2008

EVANS, G. W., OTTO, S., KAISER, F.G. 2018. Childhood origins of young adult environmental behavior. Psychological science, 295, 679-687.DOI:10.1177/0956797617741894.

GADOTTI, M. 2008. Education for sustainability: A critical contribution to the Decade of Education for Sustainable Development. Green Theory \& Praxis: The Journal of Ecopedagogy, 41, 15-64. DOI:10.3903/gtp.2008.1.3 
GERHARDS, J., \& SCHÄFER, M. S. 2010. Is the internet a better public sphere? Comparing old and new media in the USA and Germany. New media \& society, 121, 143160. DOI: $10.1177 / 1461444809341444$

GÓRECKI, A., NIESZPOREK, K., OSTRUSZKA, A., SKOLARCZYK, L., WÓJCIK, M. 2007. Świadomość ekologiczna młodzieży zamieszkującej okolice wybranych parków narodowych. Roczniki Bieszczadzkie, 5, 283-302.

GREENWOOD, J.J. 2003. The monitoring of British breeding birds: a success story for conservation science? Science of the Total Environment, 3101-3, 221-230. DOI: 10.1016/ S0048-96970200642-3

GUZAL-DEC, D., ZWOLINSKA-LIGAJ, M. 2016. Rola informacji ekologicznej w zrównoważonym rozwoju obszarów przyrodniczo cennych województwa lubelskiego. Roczniki Naukowe Stowarzyszenia Ekonomistów Rolnictwa i Agrobiznesu, 181, 59-64.

HESSELINK, F., GOLDSTEIN, W., VAN KEMPEN, P. P., GARNETT, T., \& DELA, J. 2007. Communication, education and public awareness CEPA. A toolkit for National Focal Points and NBSAP Coordinators, 310.

KALINOWSKA, A. 2011. Edukacja dla Zrównoważonego Rozwoju w Polsce - stan i wyzwania w świetle ustaleń międzynarodowych podjętych na IV Konferencji UNESCO nt. Edukacji Ekologicznej Ahmedabad 2007, IV Światowym Kongresie Edukacji Ekologicznej Durban 2007 oraz 9 Konferencji Stron Konwencji o różnorodności biologicznej Bonn 2008. Wyzwanie dla wszystkich. Uniwersyteckie Centrum Badań nad Środowiskiem.

KIRTIŞ, A. K., \& KARAHAN, F. 2011. To be or not to be in social media arena as the most cost-efficient marketing strategy after the global recession. Procedia-Social and Behavioral Sciences, 24, 260-268. DOI: 10.1016/j. sbspro.2011.09.083

KRONENBERG, J. 2012. Usługi ekosystemów w miastach. Zrównoważony rozwój-zastosowania, 3, 1428.

LEA, E., WORSLEY, T. 2005. Australians' organic food beliefs, demographics and values. British food journal. DOI: 10.1016/S0048-96970300257-2

LOVETT, G. M., BURNS, D. A., DRISCOLL, C. T., JENKINS, J. C., MITCHELL, M. J., RUSTAD, L., HAEUBER, R. 2007. Who needs environmental monitoring? Frontiers in Ecology and the Environment, 55, 253-260. DOI:10.1890/1540929520075253:WNEM2.0.CO;2

Lynx conservation campaign. 2018. WWF. https:// pomagam.wwf.pl/adoptuj/rys access 1.07.2020

MOORE, D. L., \& TARNAI, J. 2002. Evaluating nonresponse error in mail surveys. In: Groves, R. M., Dillman, D. A., Eltinge, J. L., and Little, R. J. A. (eds.), Survey Nonresponse, John Wiley \& Sons, New York, pp. 197211.
PARR, T. W., SIER, A. R., BATTARBEE, R. W., MACKAY, A., BURGESS, J. 2003. Detecting environmental change: science and society - perspectives on long-term research and monitoring in the 21 st century. Science of the total environment, 3101-3, 1-8. DOI: 10.1016/S004896970300257-2

REFEROWSKA-CHODAK, E. 2012. Ochrona przyrody w edukacji leśnej społeczeństwa. Studia i Materiały Centrum Edukacji Przyrodniczo-Leśnej, 14, 3, 32.

River sisters. 2020. Gaja Club. http://www.ratujmyrzeki. pl/ access 1.07.2020ROBELIA, B. A., GREENHOW, C., BURTON, L. 2011. Environmental learning in online social networks: Adopting environmentally responsible behaviors. Environmental Education Research, 174, 553-575. DOI: 10.1080/13504622.2011.565118

ROSA, C. D., COLLADO, S. 2019. Experiences in nature and environmental attitudes and behaviors: Setting the ground for future research. Frontiers in psychology, 10, 763. DOI: $10.3389 /$ fpsyg.2019.00763

SÁNCHEZ, R. A., CORTIJO, V., JAVED, U. 2014. Students' perceptions of Facebook for academic purposes. Computers \& Education, 70, 138-149. DOI: 10.1016/j.compedu.2013.08.012

SMITH W.G., 2008. Does Gender Influence Online Survey Participation? A Record-linkage Analysis of University Faculty Online Survey Response Behavior. San José State University, pp. 1-21; https://files.eric.ed.gov/ fulltext/ED501717.pdf

STRZELECKA, E. 2011. Rewitalizacja miast w kontekście zrównoważonego rozwoju. Budownictwo i Inżynieria Środowiska, 2, 661-668.

SWANWICK, C., DUNNETT, N., WOOLLEY, H. 2003. Nature, role and value of green space in towns and cities: An overview. Built Environment, 94-106. DOI: 10.2148/ benv.29.2.94.54467

VICENTE-MOLINA, M. A., FERNÁNDEZ-SÁINZ, A., IZAGIRREOLAIZOLA, J. 2013. Environmental knowledge and other variables affecting pro-environmental behaviour: comparison of university students from emerging and advanced countries. Journal of Cleaner Production, 61, 130-138. DOI: 10.1016/j.jclepro.2013.05.015

WEGIEL, J., SZKUDLAREK, R., WEGIEL, A., PASZKIEWICZ, R., BATOR, A. 2011. „Szlakiem Podkowca”-liczenie nietoperzy przez turystów, w sposób niezagrażający ich ochronie. Studia i Materiały Centrum Edukacji Przyrodniczo-Leśnej, 13, 3, 28. 